\title{
Executive Particularism and Ministerial Selection in India
}

\author{
Walter C. Ladwig III \\ King's College London and University of Pennsylvania
}

July 14, 2019

\begin{abstract}
Why do political parties in parliamentary systems undertake actions, such as joining a coalition government, that will entail significant costs for their members in subsequent elections? Recent research points to the incentive structures faced by differentially positioned members of a parliamentary party: unlike backbenchers, MPs who hold a ministerial portfolio can use the prerequisites of executive office to shield themselves from the costs of governance. This article tests the theory of executive particularism by examining the electoral fortunes of government ministers in India. Sitting government ministers are found to outperform other candidates, however, tests of causality fail to demonstrate that holding a ministerial portfolio causes this electoral benefit. Instead it appears that a candidate's electoral performance enhances the likelihood of being granted a ministerial portfolio in the first place. This finding raises questions about the generalizability of claims that party elites can use ministerial office to shield themselves from the costs of governing.

Keywords: Parliament; Minister; Elections; Executive Particularism; India

Word Count: 7,969 words main article. 640 words appendix.

Acknowledgements: This manuscript was the beneficiary of helpful comments and advice from Adnan Naseemullah, Avinash Paliwal, and the three anonymous reviewers. The author also thanks Gilles Verniers for sharing a draft version of the Union Cabinet Dataset
\end{abstract}

This is the author's submitted version. This article may be used for non-commercial purposes in accordance with Witey Terms and Conditions for Use of Self-Archived Versions. 
Why do political parties in parliamentary systems undertake actions, such as joining a coalition government, that they know will entail significant costs for their party in subsequent elections in the form of lost votes or seats? The opportunity to formulate legislation or the prestige of governing are two of the explanations that have been advanced to answer this question, with the maximization of policy, office, and votes often seen to competing aims. (Martin 2016) posits a novel explanation for the behaviour of parties by looking at the incentive structures faced by differentially positioned members of a parliamentary party. In contrast to backbenchers, who pay an electoral cost at the next election when their party is in office, it is argued that those MPs who hold a ministerial portfolio can use the prerequisites of executive office to shield themselves from paying such a price.

Through examination of the electoral fortunes of ministers and backbenchers in Ireland, (Martin 2016) demonstrates that MPs holding a ministerial portfolio gain a greater share of votes than their non-ministerial colleagues. Higher government office does not just provide a member of parliament with prominence or an ability to shape policy, it can also contribute to the longevity of their political career. Thus, it would appear that while backbenchers may see the pursuit of favourable policy, the formation of governing coalitions, and electoral mobilization of a core base of voters as competing priorities (Müller and Strøm 1999), ministers can have the ability to seek all three at the same time. The fact that the electoral 
incentive structure of prominent members of a party may diverge in important ways from their fellow lawmakers is a key insight that can explain why parliamentary parties may be willing to undertake politically "costly" actions like entering into a ruling coalition unpopular with the party faithful, even though their members may ultimately pay an electoral price for doing so. ${ }^{1}$

This article tests the external validity of the theory of executive particularism and the broader contention that MPs holding a ministerial portfolio can deflect the costs of governance by exploring its operation in a different electoral context. Although (Martin 2016) only studied the electoral performance of ministers in Ireland, strong claims are made as to the generalizability of the findings to other settings and electoral structures, with single-member district (UK), mixed member (Germany) and party list (Spain) parliamentary systems all explicitly identified as settings where the theory would be expected to apply. The specific causal mechanism may vary from setting to setting, (Martin 2016) notes, "but not the fundamental assertion that ministers are able to insulate themselves from the electoral costs of governing" (293). Given the considerable power wielded by ministers to direct central government spending in India it would appear they would benefit from executive particularism, although in the context of a single member district plurality electoral system

\footnotetext{
${ }^{1}$ On the electoral costs of governing, see (Paldam 1986, Paldam and Skott 1995).
} 
that differs from the multi-member district single transferrable vote system of Ireland. ${ }^{2} \mathrm{~A}$ lack of support for this theory in a case such as this where ministers exercise much more fiscal power than backbenchers would weaken our confidence in the universality of the phenomenon and suggest that the scope conditions for its applicability are narrower than previously assumed.

Examining the electoral fortunes of sitting government ministers in the four recent general elections in India (1999-2014) reveals that those holding high offices do experience an electoral bonus in the form of an increased share of the vote. This finding would appear to bolster the case for executive particularism, however, when it comes to causality it is not possible to demonstrate that holding office in India is the factor that produces this superior electoral performance. Instead, MPs with a superior electoral performance are more likely to be given a ministerial portfolio in the first place. These results raise questions about the generalizability of the theory of executive particularism and indicates that much more investigation is necessary into the factors which enable sitting government ministers to leverage their office to avoid the costs of governance.

\footnotetext{
${ }^{2}$ (Martin 2016,293) offers the UK as an example of a location where executive particularism would be expected to function. Thus, a W estminster-style parliamentary system would be not obviously be outside the scope conditions for this theory.
} 


\section{Ministerial Office and the Cost of Governing}

(Martin 2016) advances the notion that the actions of parliamentary parties can be understood as a product of the dissimilar electoral incentives facing differentially positioned members of the party. The electoral fortunes of government ministers are distinguished from those of their fellow party members by the ability to leverage their office to gain votes and therefore avoid paying the electoral costs of governing. The mechanism that explains this phenomenon is "executive particularism." Ministers can target their own constituents with a form of pork-barrel government spending that is not available to backbench MPs. In turn, the expectation is that constituents will reward this enhanced government spending at the ballot box. Although legislative particularism is not believed to be a common phenomenon in parliamentary systems, numerous examples from Great Britain, Ireland, Sweden, Italy, and Australia all suggest that ministers in parliamentary systems are uniquely endowed with the ability to direct a disproportionate share of central government spending to their own supporters (Martin 2016, 285). ${ }^{3}$ Though not all ministerial offices are equal in their ability to directly distribute patronage, (Martin 2016, 285-6) contends that all ministers gain an electoral benefit from serving in the government. This is a result of the cartel-like nature of cabinet government whereby ministers trade off benefits among themselves to ensure that the

\footnotetext{
${ }^{3}$ On legislative particularism in parliamentary systems, see (W ehner 2010).
} 
interests of all ministers (and therefore their constituents) are advanced by targeted government spending. ${ }^{4}$ Thus, those MPs who hold a ministerial portfolio have access to an exclusive electoral advantage vis-à-vis their fellow party members who sit on the back benches, which protects them from having to pay the electoral "cost" of governing that rank-and-file MPs must bear. This leads to our test hypothesis that:

$\mathrm{H}_{\mathrm{A}}$ : Candidates holding a ministerial portfolio ahead of a general election gain a larger share of the vote than backbenchers and other candidates.

\section{Electoral Performance and Cabinet Selection}

Though the basic logic of executive particularism is compelling, there are reasons to question whether it is the holding of ministerial office that leads to an electoral advantage. Instead, prior scholarship has identified a link between a candidate's electoral performance and their likelihood of ministerial appointment in the first place. (O'Malley 2006) reports that in Ireland - where the theory of executive particularism was validated - "the most important variable to predict likelihood of cabinet membership is personal vote" (332), with cabinet ministers achieving a higher share of the electoral quota than junior ministers or backbenchers. Similarly, in both the UK (Kerby 2009, Klein and Umit 2016) and Canada (Kerby 2009, Klein

\footnotetext{
${ }^{4}$ This is different than the "procedural cartel theory" put forth by (Cox and M cC ubbins 2004).
} 
and Umit 2016), an MP's winning vote margin - their degree of electoral safety - has been found to be positively associated with their chance of ministerial appointment.

There are at least two appointment logics that would dictate an MP's vote margin was positively associated with their chance of ministerial appointment. First, the ministerial selectorate could view electoral performance as a proxy for other harder to measure attributes such as "political capital, constituency support, organizational ability, or finesse" (Kerby $2009,602)$. The performance of specific ministers is key to the development and execution of policy in parliamentary systems (Dowding and Dumont 2009, 5-6), however, in terms of skills and abilities, politicians from the same party are far from interchangeable (Blondel 1993). Since it is not always possible for a prime minister or party leader to directly observe every single MP and determine which ones have what it takes to succeed in a ministerial role, electoral success could plausibly serve as a heuristic for sorting ministerial candidates.

Alternately, the ministerial selectorate might focus on an appointing MPs with strong electoral performance because they are primarily worried about holding seats and winning future elections. A central proposition in the comparative literature on the behavior of legislatures is that the electoral connection (Mayhew 1974) influences the strategic behavior of individual politicians. Such incentive structures should also condition the behavior of Prime Ministers and party leaders. Ruling parties or governing coalitions want to retain their 
privileged position, which requires sustained electoral success. Consequently, the selection of cabinet ministers should be affected by this vote seeking goal. A senior post in government can consume a great deal of a politician's time, which comes at the expense of their role as a constituent representative. As (Strøm 1997) has argued, seeking a ministerial portfolio "is a potentially treacherous pursuit for MPs who face stiff competition for reselection or re-

election" (169). Those MPs who are best positioned to devote time and attention to a demanding ministerial role are the ones who do not have to worry about re-election.

Irrespective of the specific appointment strategy, the arguments presented above suggest a positive relationship between electoral success and ministerial appointment. In contrast to the hypothesis from the prior section which contends that the holding of ministerial office leads to superior electoral performance, the association between cause and effect are reversed here. This leads to the alternate hypothesis:

$\mathrm{H}_{\mathrm{B}}$ : An MP's likelihood of being appointed as a minister is positively correlated with the margin by which they win their seat.

\section{Data and Empirical Strategy}

To test the external validity of the theory of executive particularism versus the conjectured link between electoral performance and cabinet selection, we have assembled a new dataset 
of candidate-level electoral results from recent Indian parliamentary elections (1999-2014). There are a number of factors that commend India as a venue for this analysis. First, national politics in India appears to possess the necessary prerequisites for executive particularism: backbenchers in the Indian parliament have little ability to affect the operations of government ministries while government ministers exercise a high degree of influence over the central government's various discretionary grant programs, which are delivered by individual ministries. Prior scholarship on Indian government spending suggests that these grants are disproportionately allocated to states to advance the partisan political interests of the ruling government (Arulampalam, et al. 2009). Moreover, in line with the various national examples of parliamentary executive particularism cited by (Martin 2016), there is also evidence from India that the home states of government ministers receive a larger share of discretionary government grants than states without ministers in the government (Biswas, et al. 2010). In the popular media, allegations abound that ministers employ their offices to benefit their constituents, with the Railway Ministry seen as perhaps the most notorious example. In a 2013 editorial calling for the railways to be run by an independent agency, for example, the Times of India noted that "the Railways are cynically seen as an avenue for giving jobs and contracts, a huge patronage machine. Railway Ministers constantly sanction new, low-priority railway trains for their favored constituencies, or create new regional headquarters to justify 
additional jobs in a grossly overstaffed organization" ("De-Politicize Railways, Create Independent Corporation" January 13, 2013). ${ }^{5}$

Study of the electoral benefits of executive office in India is important because, as a developing country, it is often excluded from comparative studies of government formation. Instead, existing literature on ministerial appointments and cabinet reshuffles overwhelmingly tests hypotheses against data drawn from Europe, North America, and other advanced industrialized democracies. Finally, as (French 2011) notes, "half of the people in the world who live in a democracy live in India" (67). Thus, Indian general elections routinely rate as the largest electoral exercises in human history, which makes the Indian experience intrinsically important for our broader understanding of democratic electoral processes.

\section{The Government of India}

India is a parliamentary republic that combines a federal state structure with a Westminsterstyle system of government. The primary legislative chamber of the country's bicameral parliament is the lower house or the Lok Sabha (House of the People). Members of the Lok

\footnotetext{
${ }^{5}$ On patronage politics in India more generally, see (W ilkenson 2014)
} 
Sabha are directly elected from 543 constituencies in single-member plurality elections. ${ }^{6}$ Additionally, the legislatures of each of the country's 36 states and union territories indirectly elect representatives to the upper house of the, the Rajya Sabha (Council of States).

Executive authority in India is exercised by the Union Council of Ministers. Aside from the Prime Minister, members of the Council of Ministers generally consist of officials of two types. ${ }^{7}$ Cabinet Ministers oversee an entire government ministry and are charged with developing and implementing policy in line with the government's objective. Ministers of State are more junior in rank and can either be assigned to assist a Cabinet Minister or be given an "independent charge." Under the Indian Constitution the overall size of the government must not exceed $15 \%$ of the size of the Lok Sabha ( 81 ministers) and all members of the government must hold a seat in one of the two houses. ${ }^{8}$ The Council of Ministers is collectively responsible to the lower house and is required to resign should a no-confidence motion against it be passed (Nikolenyi 2014, 108). Therefore, although some government ministers are selected from the Rajya Sabha, they primarily come from the Lok Sabha (Jain $2003,34)$.

\footnotetext{
${ }^{6}$ There is an additional provision to appoint two members to represent the Anglo-Indian community, but since these members are not elected, we do not consider them in this present study. (Nikolenyi 2014, 100). ${ }^{7}$ Historically the Council of M inisters has also included Deputy M inisters and Parliamentary Secretaries, but the use of these positions has fallen out of practice in the contemporary era. (J ain 2003, 14).

${ }^{8}$ If a sitting minister finds themselves without a legislative seat, they have six months to secure one.
} 
Since only members of the Lok Sabha are directly elected, this study focuses solely on candidates running for office in the lower house. In order to evaluate the electoral advantage enjoyed by sitting government ministers, we have collected information on all candidates who took part in four recent Indian general elections $(1999,2004,2009$, and 2014). This resulted in a data set with 26,405 candidate observations of 23,363 unique individuals contesting office on behalf of 786 different political parties, plus independents. To assess our alternative hypothesis on the link between electoral performance and cabinet appointment, we focus on a subset of this data - parliamentarians from all ruling governments between 1999-2019since they were the only candidates eligible for ministerial appointment.

Information on election results as well as candidate's vote share and their party affiliation were taken from the website of the Electoral Commission of India. ${ }^{9}$ Candidates who were sitting members of parliament running for reelection were identified from member profiles on the Lok Sabha website. ${ }^{10}$ Biographical details of MPs, including information on their past parliamentary and other political experience were acquired from the aforementioned member profiles as well as ministerial records curated by the Parliament of India (Lok Sabha Secretariat 2011). Where necessary, this data was supplemented by information from the

\footnotetext{
${ }^{9}$ Statistical Reports of General Election T o Lok Sabha, Electoral Commission of India, eci.gov.in/statisticalreport/ statistical-reports.

${ }^{10}$ Lok Sabha M ember's Biographical Sketches, Parliament of India, 164.100.47.194/ Loksabha/ M embers/ lokprev.aspx.
} 
Union Cabinet Dataset held by the Trivedi Center for Political Data at Ashoka University and information on MP's legislative activities assembled by PRS Legislative Research. ${ }^{11}$

\section{Research Design: Executive Particularism}

In order to assess the effect of holding ministerial office on subsequent electoral outcomes, we estimate a linear regression that examines a candidate's electoral success in terms of their share of the vote in the constituency being contested. With Vote Share, the percentage of votes received by candidate in $_{\mathrm{i}}$ constituency $\mathrm{y}_{\mathrm{i}}$, as the dependent variable, this is modeled using ordinary least squares. Across the four general elections studied here, the median successful candidate won $47 \%$ of the vote, beating their nearest opponent by $9.5 \%$. The closest races were decided by less than $1 / 10^{\text {th }}$ of $1 \%$ of the vote and the biggest winner garnered a vote margin of $70.1 \%$.

Since the hypothesis under consideration is that possessing a ministerial portfolio will be an advantage to incumbent candidates going into a general election, our key independent variable is whether or not a candidate held ministerial office immediately prior to the election. To assess this, a dichotomous variable, Ministerial Office, is used which takes a 1 if a given

${ }^{11}$ T rivedi Centre for Political Data, tcpd.ashoka.edu.in. M P T racker, PRS Legislative R esearch, www.prsindia.org/ mptrack. 
candidate was a cabinet minister or minister of state at the time the general election was called and a 0 otherwise. The expectation of the theory of executive particularism is that the electoral rewards are reaped at the most proximate general election. Voters do not continue to reward former ministers for their historical performance. Consequently, if a candidate had been a minister at some point during the given parliamentary session but resigned their post or was the victim of a cabinet reshuffle, they are coded with a zero as they are not in office at the time of the election. To distinguish the specific effects of holding ministerial office from the general electoral impact of being a sitting member of parliament, an Incumbent control variable is included in the basic model. This takes a value of 1 if the candidate was a member of parliament at the time the general action was called and a 0 otherwise. Robust standard errors clustered by individual are included in all specifications. ${ }^{12}$

Expanded versions of the models include some additional control variables. One factor that can affect an individual candidate's electoral prospects is party membership. Although more than $43 \%$ of the candidates in our sample stood as independents - without a party

\footnotetext{
12 Identification of repeat observations was complicated by the substantial number of observations and the fact that candidate names were not always transliterated consistently from election to election. For example, JD(U) MP A rjun Roy was identified as A rjun Rai in the 2014 election results while former BSP MP K aisar J ahan was identified as $\mathrm{K}$ aiser J ahan in a subsequent election. When there were questions as to whether a given pair of observations were of the same individual - particularly when a candidate had changed parties and constituencies between elections electoral affidavits maintained by the National Election W atch (www.myneta.info) were consulted to match pairs on factors such as father's name, home address, education level and degree-granting institution, as well as age.
} 
affiliation - they only won $1.1 \%$ of races. Thus, it is reasonable to assume that attachment to a political party in general and the identity of that party in particular can have a bearing on a candidate's electoral success. The Party control variable assigns a separate category to each of the recognized national and state-level political parties as well as a category for parties not recognized by the Electoral Commission of India and a category for independent candidates.

To account for the fact that the effects of incumbency, as well as a candidate's general election prospects, may differ depending on whether their party was in government or in the opposition, a Government variable is added. This is a dichotomous variable taking a value of 1 if the candidate's party was part of the ruling coalition immediately prior to the election and a 0 otherwise. ${ }^{13}$ To capture the specific effects of being a sitting MP from the ruling party, an interaction term (Incumbent* Government) is also included.

Although (Martin 2016) did not identify a unitary state, such as Ireland, as a necessary condition for executive particularism, given India's federal structure, it is possible that political dynamics at the state-level can affect a minister's ability to deploy executive particularism for electoral gain. To account for that, we add a State Governing Party variable

${ }^{13}$ In keeping with (M artin 2016), if a party withdraws from the ruling coalition at some point before a general election they are still coded as having been part of the government. 
that takes a 1 if an MP's party is part of the ruling coalition at the state level. A second interaction term (Ministerial Office* State Governing Party) is included as well. Finally, to account for electoral trends at the local level, as well as over time, constituency-year fixed effects are included.

\section{Research Design: Electoral Success and Ministerial Appointment}

To assess the alternate hypothesis that MPs with superior electoral performance are more likely to be appointed to cabinet office in the first place, we focus on candidates who won election to the Lok Sabha from the various ruling coalitions that held power between 1999-2019. Since the prime minister is selected by the president and has the authority to select ministers, they are not included in our sample of potential ministers. We also exclude MPs who died in office, were expelled, or otherwise failed to serve a full parliamentary term because they did not have a full opportunity to be considered for appointment. This produces a total of 1,116 MP observations of 977 unique individuals, each of whom theoretically had the potential to be given a ministerial portfolio. Data on the career path and background of

each of the MPs in the governing coalition for a given Lok Sabha was assembled from the sources described previously to collect the same information on those who were successful at being appointed to higher office, as well as those who were not. 
We examine the effect of electoral performance on the likelihood of appointment as a government minister by estimating a series of logit models with a binary dependent variable, Minister, taking a 1 if an MP is appointed to a ministerial office during a given parliamentary session and a 0 if they remain on the backbenches. Our independent variable of interest is the electoral margin by which each MP won their seat. In line with existing literature on electoral incentives for parliamentary behavior in single-member districts (Bowler 2010, Kellermann 2016), Vote Margin is taken as the percentage of votes won by the MP minus the percentage given to the second-place candidate. As table 1 indicates, the average government MP won their seat with a margin of $12.99 \%$, while the least secure seat in the sample had just a $0.03 \%$ margin over the challenger and the most secure MP held a majority of $57.24 \%$.

In addition to these two core variables, we estimate a series of models that control for an MP's prior political experience and relevant personal attributes. There is a limited literature on the appointment of government ministers in India. Early works largely focused on describing the social characteristics of ministers. In the first decades after independence, those who became ministers were better educated and from more urban settings than the population as a whole (Arora 1972,1523-5). Up to $40 \%$ of cabinet ministers in these early years achieved their rank without prior parliamentary experience (Arora 1972, 1525). Those ministers with a parliamentary background, however, were more likely to lead one of the core 
ministries (Defense, Home, Finance, and External Affairs) than those appointees who were new to the Lok Sabha (Nicholson 1975, 542). During the 1970s the average minister became younger and their substantive backgrounds changed. Under Jawaharlal Nehru's premiership (1947-1964), 70\% of ministers had made their name in national politics, having never held office at the state level (Sisson 1981,143). In contrast, under Indira Gandhi, from the late 1960s to the late 1970 s between $70-85 \%$ of ministers had their substantive political experience at the state level, entering the government without any prior service in the Lok Sabha (Sisson 1981, 152). In both periods, ministers were overwhelmingly male: just five female cabinet ministers were appointed in the 48-year period from 1952-2000, all but one since 1979 (Jain $2003,33)$. In India there is no principle of guaranteed representation for women in the Council of Ministers (Jain 2003, 31). Although there have been some high-profile female politicians in the country —including its most controversial prime minister - in general, as (Basu 2010) notes, "parties have done little to provide women access to the networks and resources that would enable them to ascend the ranks of party hierarchies" (168). Recent work on cabinet composition in India has primarily focused on inter-party negotiations (Nikolenyi 2004, Sridharan 2012; Nikolenyi 2015). However, descriptive analysis of cabinet composition since 1989 has confirmed continuity in several prior trends, with education continuing to be important, while average age has increased, and national political experience once again has emerged as a common trait (Jain 2003,30-1; Nikolenyi 2014, 107-8). 
Reflecting the federal nature of government in India, we account for prior legislative and executive service at both the national and the state level. The Parliamentary Experience variable measures the number of years the MP has served in the national parliament. Since some MPs move back and forth between the Lok Sabha and the Rajya Sabha, and the latter retains substantive legislative duties, the years of service in either house are aggregated. ${ }^{14}$ The Ministerial Experience variables capture the number of years of prior experience a member of parliament has in the national executive. Turning to state-level variables, Legislative Assembly Experience records the number of years an MP served in one of the country's unicameral or bicameral state legislatures. State-level government could offer an opportunity to cultivate executive experience that would be relevant for national politics. The Chief Minister and State Cabinet variables capture the number of years than an MP served as the chief executive of a state or as a member of the state government respectively.

The literature on ministerial characteristics noted above identified several personal traits that could affect an MP's chances of being given a ministerial portfolio, including their gender, their age, and their education level. Since it might be expected that male MPs have an easier path to higher office than their female counterparts, we control for Gender as a binary variable recording a 1 for female parliamentarians and a 0 for males. Age is a personal

\footnotetext{
${ }^{14}$ It makes no substantive difference to the results to separate Lok Sabha and Rajya Sabha experience into
} two separate variables. 
attribute that many observers hypothesize affects the likelihood of ministerial selection. The variable Age measures the MP's age at the start of a given parliamentary session. As of the most recent census, nearly $37 \%$ of the Indian population is illiterate and just $8 \%$ has completed tertiary education (Shrinivasan August 4, 2015). Educational attainment could indicate that an MP has the mental acuity for higher office. The variable Bachelor's takes a 1 if the MP in question has at least an undergraduate degree and a 0 otherwise.

Table 1. Descriptive Statistics of Government MPs

\begin{tabular}{llllll}
\hline & Mean & Median & Minimum & Maximum & SD \\
Vote Margin & 12.99 & 11.03 & 0.03 & 57.24 & 9.95 \\
Parliamentary Experience & 4.31 & 1.13 & 0 & 40.59 & 6.15 \\
Ministerial Experience & 0.45 & 0 & 0 & 15.58 & 1.51 \\
Legislative Assembly Experience & 4.14 & 0 & 0 & 37.00 & 6.62 \\
Chief Minister Experience & 0.12 & 0 & 0 & 16.00 & 0.92 \\
State Cabinet Experience & 0.85 & 0 & 0 & 19.00 & 2.42 \\
Age & 54.22 & 55 & 20 & 89 & 11.79 \\
\hline
\end{tabular}

Note: All variables are measured in years, apart from Vote Margin

Finally, to account for idiosyncratic factors affecting the ministerial selectorate in each government studied here, including the predilections of a given prime minister, fixed effects for each Lok Sabha (parliamentary term) are also included in the models, with the $13^{\text {th }}$ Lok Sabha as the excluded group. 


\section{Does Office Lead to Votes?}

As reported in Table 2, models 1-5 employ Vote Share as the dependent variable and a linear regression to examine the link between holding a ministerial portfolio and subsequent electoral success. The first model only includes Ministerial Office and Incumbent without any additional control variables or fixed effects, while the second incorporates the Government

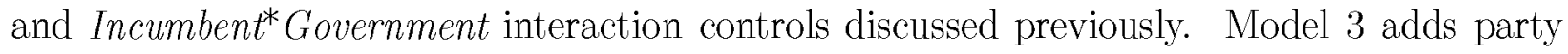
fixed effects, model 4 adds constituency-year fixed effects and model 5 incorporates both. For ease of presentation, the coefficients and standard errors for the party fixed effects are not produced here. ${ }^{15}$

These five models produce results in line with (Martin 2016)'s prior findings. Both the basic and extended specifications demonstrate that, controlling for incumbency status, sitting ministers enjoy an electoral advantage over their fellow party members. In every case, the coefficient for ministerial office is positive and statistically significant, suggesting that those MPs holding a ministerial portfolio see an increase in their vote share in subsequent elections.

At the same time, the statistically significant negative coefficient for Incumbent* Government demonstrates the cost of governing borne by all members of the ruling party. Ceteris paribus,

${ }^{15}$ These sets of fixed effects are strictly for control purposes and are not integral to the theoretical propositions being examined here. 
sitting government ministers win a larger share of the vote in a subsequent election than backbenchers in the same party.

Model 5 indicates that on average candidates holding ministerial office gain an additional $2.6 \%$ of the vote. While this a may not seem like a significant amount, of the 2,172 successful candidates in our dataset, $337(15.5 \%)$ won office by a margin of $2.6 \%$ or less. Compared to opposition incumbents, model 5 indicates that backbench MPs from the ruling party can expect their vote share to be an average of $6.4 \%$ lower while sitting ministers can expect to lose just 3.8\%. Although they cannot completely avoid paying a price, these findings suggest that sitting government ministers can deflect more than $40 \%$ of the "cost" of ruling.

[Table 2 about here]

One key difference between Ireland, where the theory of executive particularism was tested, and India is that the former is a unitary state and the latter has a federal system of government. (Martin 2016) gave no indication that federalism should affect the functioning of executive particularism and even identified Germany, a federal state, as a political system where the theory would be expected to operate. Nevertheless, model 6 and 7 account for the possibility that an opposition party holding power at the state level may affect a minister's ability to deploy government spending in a manner that boosts their electoral prospects. Model 6 adds the State Governing Party variable to model 5 while model 7 adds an interaction 
between Ministerial Office and State Governing Party as well. In model 6, neither the sign nor the significance of Ministerial Office changes as a result of controlling for the ruling party at the state level. Interpretation of the final model is slightly less straightforward. The presence of an interaction term including our key independent variable means the coefficients for both Ministerial Office and State Governing Party no longer indicate the marginal effect, but rather the effect of that variable when the moderator is equal to zero \{Kaufman, 2019 \#273\}. Employing the SIGREG tool from the ICALC Toolkit for Stata reveals that Ministerial Office remains statistically significant when the interaction effect is included. ${ }^{16}$ The results indicate that the effect of holding ministerial office on vote share is affected by the identify of the party that is governing at the state level. In particular, it suggests executive particularism may have a greater electoral benefit when employed in a state were the minister's party is not currently in charge. Thus, subnational political dynamics appear to be a consideration when assessing the utility of executive particularism.

\section{Testing Causality}

\footnotetext{
${ }^{16}$ Robert L. Kaufman, ICALC Toolkit for Stata Users, icalcrlk.com
} 
The results discussed above only identify a correlation between holding cabinet office and achieving a higher vote share. This does not tell us that holding cabinet office causes these outcomes. Absent the ability to randomly distribute cabinet portfolios, we must be circumspect when discussing the insights into causal mechanisms and the direction of effects derived from observational data. In an effort to isolate the causal effect of holding cabinet office on a candidate's performance in the following election, we undertake an additional test that focuses exclusively on the subset of candidates who were sitting MPs that stood for reelection (Incumbent $=1$ ). The dependent variable is the change in vote share that occurs between elections. For each candidate, the vote share they received in the election at time $t$ 1 is subtracted from the share of votes won in election $t$. If, as the theory of executive particularism postulates, holding ministerial office is responsible for the enhanced electoral fortunes of candidates, it should be possible to observe and measure it directly. Only MPs who stand for reelection from the same constituency are included in our sample in an effort to confine the variation between the two periods to the effects of holding parliamentary office and serving as a government minister. Thus, the personal characteristics of individual candidates and the particular traits of their constituencies are controlled for by comparing the same persons contesting the same seats at different points in time. Across four general elections, this produces a pool of 1,546 incumbent observations. 
Mirroring the approach undertaken by (Martin 2016), the change in vote share resulting from the holding of ministerial office is estimated in an OLS model. As with our first set of models, the independent variable is Ministerial Office and includes Government as a key control variable. The results in Table 3 demonstrate, as politicians around the world know all too well, that there is indeed a cost to governing. Compared to incumbents from opposition parties, sitting MPs running for reelection on a governing party ticket experienced Table 3. Ministerial Office and Vote Share in Subsequent Election

\begin{tabular}{ll}
\hline Minister & -0.006 \\
& $(0.010)$ \\
Government & $-0.021^{* *}$ \\
& $(0.007)$ \\
Constant & $-0.061^{* * *}$ \\
& $(0.005)$ \\
Observations & 1,546 \\
R-squared & 0.008 \\
\hline \hline
\end{tabular}

Note: Robust standard errors clustered on individual candidates in parentheses

*** $\mathrm{p}<0.001,{ }^{* *} \mathrm{p}<0.01,{ }^{*} \mathrm{p}<0.05$

a decrease in their vote margin in the subsequent election. Critically, this assessment does not indicate that government ministers in India experience a statistically significant change to their vote share between election $t-1$ and election $t$. Thus, we do not find causal evidence that ministerial office shields candidates in India from the "cost" of governance. Instead, this sample of incumbent candidates suggests that government ministers and backbenchers suffer 
the same electoral losses from belonging to a party that is part of a ruling coalition. The robustness of this finding is examined in a series of difference-in-difference models that appear in the online appendix. These also offer no evidence that the electoral performance of sitting government ministers is enhanced by holding office.

On the basis of these results, we cannot conclude that the superior election results achieved by government ministers vis-à-vis backbenchers, which was reported in table 2 , ix explained by their ability to manipulate the privileges of executive office. Indian politicians may covet a ministerial portfolio for the prestige the post conveys or for the opportunity to shape policy, but heightened electoral performance is not one of the rewards ministers reap.

As noted earlier, prior scholarship indicates that central government spending in India is disproportionately allocated to favor sitting government ministers and advance partisan political interests. Thus, there is good reason to believe that the necessary conditions for executive particularism to function should be found in this case. The lack of evidence of a causal link between holding a ministerial portfolio and increased vote share in a situation where the circumstances are favorable for the theory provides an important challenge to generalizability of executive particularism and broader claims that party elites can use executive office to shield themselves from the costs of governing. 


\section{Do Votes Lead to Office?}

What of the alternative proposition, that a correlation between ministerial office and vote share is best explained by the fact that a candidate's electoral performance affects their chances of ministerial appointment? This hypothesis is examined by four logistical regression models which employ pooled data for all government MPs in the dataset and are presented in Table 4. The first specification contains the test variable, Vote Margin, with no additional control variables. Model 2 adds fixed effects for the parliamentary term to the first specification. Model 3 adds the political experience variables to Model 2, while model 4 controls for an MP's personal traits instead.

As table 4 indicates, in models 1-4 vote margin is positively correlated with the chance that an MP is allocated a government portfolio, even when controlling for prior political experience and key personal traits. In terms of the effect that a change in vote margin has on the likelihood of being appointed as a government minister, holding all other variables at their mean, an MP with the minimal electoral safety has a $19 \%$ of being selected while the chances of appointment for an MP coming from the safest seat rises to $44 \% .{ }^{17}$ These results are

\footnotetext{
${ }^{17}$ This calculation is based on model 3. All control variables are held at their respective means.
} 
Table 4. Electoral Performance and Ministerial Appointment

\begin{tabular}{lcccc}
\hline \hline & $(1)$ & $(2)$ & $(3)$ & $(4)$ \\
\hline Vote Margin & $0.014^{*}$ & $0.023^{* *}$ & $0.020^{* *}$ & $0.021^{* *}$ \\
& $(0.007)$ & $(0.007)$ & $(0.008)$ & $(0.007)$
\end{tabular}

Political Experience Controls

Parliamentary Experience

$0.081^{* * *}$

Ministerial Experience

$(0.015)$

$0.234^{* *}$

(0.076)

Leg. Assembly Experience

0.023

Chief Minister Experience

0.086

$(0.074)$

State Cabinet Experience

0.025

(0.038)

$\underline{\text { Personal Trait Controls }}$

Gender

0.426

$(0.244)$

Age $0.025^{* * *}$

Bachelor's Degree $(0.007)$ $0.418^{*}$ $(0.200)$

\begin{tabular}{lllll} 
Parliamentary-term fixed effects? & No & Yes & Yes & Yes \\
Log-likelihood & -629.6 & -620.5 & -557.9 & -609.3 \\
AIC & 1263.3 & 1251.1 & 1137.8 & 1234.6 \\
\hline \hline
\end{tabular}

Note: Robust standard errors clustered on individual candidates in parentheses ${ }^{* * *} \mathrm{p}<0.001,{ }^{* *} \mathrm{p}<0.01,{ }^{*} \mathrm{p}<0.05$

displayed graphically in figure 1 and support the claims of $H_{B}$ that the likelihood of appointment as a government minister is correlated with an MP's electoral performance. 


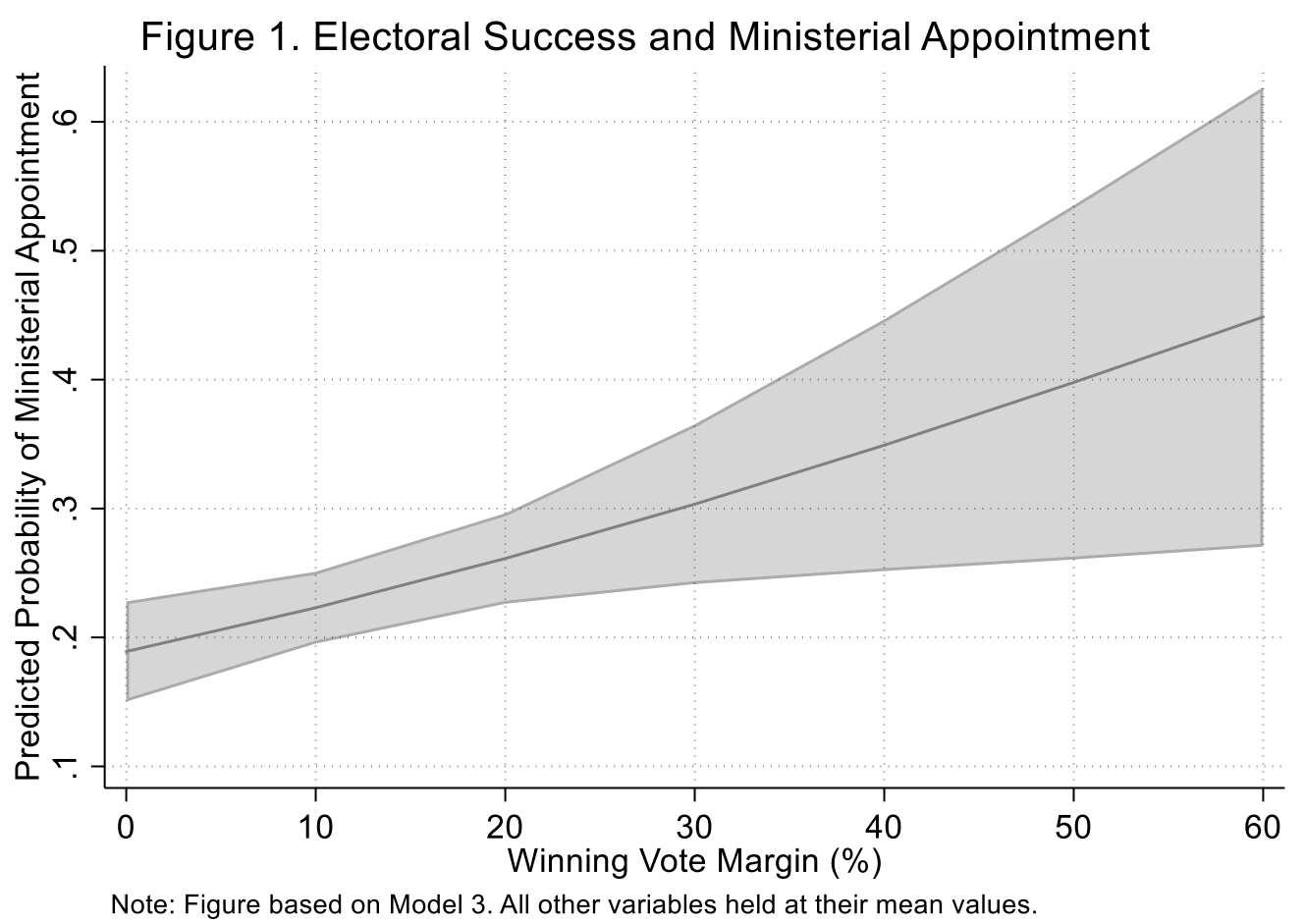

As with the hypothesis in the prior section, it is necessary to subject the observed correlation between electoral performance and ministerial appointment to an assessment of the direction of causality. To accomplish this, we focus on a subset of 958 MPs in our sample who have never previously served as a government minister at the national level. This allows us to scrutinize the effect of electoral performance on the prospect of a ministerial appointment without the potentially confounding effects of prior executive service on an MP's vote margin. Table 5 reproduces model 3 and 4 from table 4 , but employs an abridged sample of MPs without prior experience as either a cabinet minister or minister of state. As the two models indicate, Vote Margin remains positively associated with the likelihood of a ministerial 
Table 5. First Ministerial Appointment

\begin{tabular}{lll}
\hline & \multicolumn{1}{c}{$(1)$} & \multicolumn{1}{c}{$(2)$} \\
\hline Vote Margin & $0.019^{*}$ & $0.018^{*}$ \\
& $(0.009)$ & $(0.008)$ \\
Political Exp. Controls & & \\
\hline Parliament Experience & $0.089^{* * *}$ & \\
Leg. Assembly Experience & $(0.018)$ & \\
& 0.022 & \\
Chief Minister Experience & $(0.017)$ & \\
& 0.206 & \\
State Cabinet Experience & $(0.155)$ & \\
& 0.022 & \\
Personal Trait Controls & $(0.042)$ & \\
Gender & & 0.270 \\
Age & & $(0.277)$ \\
& & $0.016^{*}$ \\
Bachelor's Degree & & $(0.008)$ \\
& & 0.363 \\
Parliamentary-term fixed effects? & Yes & $(0.218)$ \\
Log-likelihood & -439.756 & -453.003 \\
AIC & 897.511 & 922.005 \\
\hline \hline
\end{tabular}

Note: Robust standard errors clustered on individual candidates in parentheses

${ }^{* * *} \mathrm{p}<0.001,{ }^{* *} \mathrm{p}<0.01,{ }^{*} \mathrm{p}<0.05$

appointment, even when controlling for political experience and personal traits. In conjunction with the failure to establish a causal link between holding ministerial office and 
increased vote share in a subsequent election discussed in the prior section, these results give us confidence that, in India, it is electoral performance that bolsters the likelihood of ministerial selection, not vice-versa.

\section{Discussion}

In examining the electoral value of ministerial office, (Martin 2016) makes an important contribution to our understanding of the behaviour of political parties by identifying a potential cleavage in electoral incentive structures faced by serving government ministers and their backbench colleagues. Such a finding could help us better understand why political parties are willing to take actions that will have costly electoral consequences for its members. The answer, (Martin 2016) suggests, is that not all party members bear the costs of governance equally. In fact, the most senior or prominent members of the party - those who hold ministerial portfolios - may be able to exploit the pre-requisites of their office to avoid paying the "cost" of governing. Aside from the commonly understood benefits of policymaking and the prestige of office, this line of argument suggests that holding a ministerial portfolio can assist a politician pursue votes as well.

This present study tested the external validity of this theory of executive particularism by moving beyond the tiny testbed of Ireland to the sprawling federal system that is India. 
The results raise questions about the ability of government ministers writ large to leverage their post to avoid paying the "cost" of governance that must be borne by their colleagues on the backbenches. Examination of general election results in India confirm that sitting government ministers achieve superior electoral outcomes compared to the rank-and-file members of their parliamentary party. A controlled comparison of the election results of incumbent MPs standing for re-election from the same constituency, however, could not demonstrate that holding cabinet office caused a candidate's vote share to change between a given pair of elections in a manner that was different from backbenchers in the same party. This result raises critical questions about the external validity of the theory of executive particularism. On the face of it, India has many of the necessary conditions in place for the phenomenon to occur, which arguably renders it an easy case for confirming the theory. Yet, the holding of office there does not appear to be the cause of the superior electoral performance by government ministers. Instead, it appears that those candidates from the ruling party who perform particularly strongly in a given election are more likely to be allocated a government portfolio in the first place. This echoes the links between electoral performance and ministerial appointment that have previously been reported in Ireland (O'Malley 2006), Canada (Kerby 2009), and the UK (Klein and Umit 2016), among other locales. 
Overall, the results reported here raise some important questions for the universality of the argument holding a government portfolio shields ministers from the costs of ruling and indicate that further refinement of the scope conditions and deeper exploration of the phenomenon is necessary. Two avenues of further research flow from this study. First, the inability to identify a causal link in the Indian data between serving as a cabinet minister and the superior vote share that ministers achieve suggests a broader investigation into causal mechanisms is necessary. As noted in the introduction, (Martin 2016) makes a strong argument that the ability of ministerial to deflect electoral costs is a universal phenomenon. In both Ireland and India, central government ministers have the ability to direct discretionary government spending. Why aren't Indian ministers able to leverage their office to deflect the "costs" of governance in the way that their Irish counterparts can? In particular, future research could focus on developing a better understanding of the necessary conditions for executive particularism to function.

Second, although this study did not confirm (Martin 2016)'s theory on the electoral benefits of ministerial office, in demonstrating that electoral incentives affect the allocation of government posts in India it contributes to our understanding of the relationship between ministerial office and elections as well as the way the two shape the behaviour of political parties. Existing scholarship on the composition of cabinets and the distribution of important 
ministerial portfolios tends to focus on the question of which political party gains a particular portfolio and why. This party-level focus is understandable given the frequency with which coalitions govern contemporary parliamentary democracies as well as the fact that the allocation of cabinet posts can significantly affect a government's policy agenda (Bäck, et al. 2011). Despite the importance of the individuals who serve in a cabinet, there has been far less scholarly attention given to the question of why parties allocate cabinet posts to particular politicians than there has been to the distribution of these portfolios between parties in the

government. Just as (Martin 2016) sought to bridge the dissimilar literatures on the behavior of political parties and the electoral incentives shaping the behavior of individual legislators, future research would benefit from connecting to the growing research on ministerial selection and portfolio allocation as well. A better understanding of the candidates themselves and the factors that lead one MP to be given a ministerial portfolio and not another would also be a useful addition to our understanding of the government formation process.

\section{References}

Arora, Satish K. 1972. "Social Background of the Indian Cabinet." Economic and Political Weekly 7: $1523-32$.

Arulampalam, Wiji, Sugato Dasgupta, Amrita Dhillon, and Bhaskar Dutta. 2009. "Electoral Goals and Center-State Transfers: A Theoretical Model and Empirical Evidence from India." Journal of Development Economics 88: 103-19. 
Bäck, Hanna, Marc Debus, and Patrick Dumont. 2011. "Who Gets What in Coalition Governments? Predictors of Portfolio Allocation in Parliamentary Democracies." European Journal of Political Research 50: 441-78.

Basu, Amrita. 2010. "Gender and Politics." In The Oxford Companion to Politics in India, ed. Niraja Gopal Jayal and Pratap Bhanu Mehta. New Delhi: Oxford University Press.

Biswas, Rongili, Sugata Marjit, and Velayoudom Marimoutou. 2010. "Fiscal Federalism, State Lobbying and Discretionary Finance: Evidence from India." Economics 69 Politics 22: 68-91.

Blondel, Jean. 1993. "Individual Ministers and Their Role in Cabinet Decision-Making." In Governing Together: The Extent and Limits of Joint Decision-Making in Western European Cabinets, eds. Jean Blondel and Ferdinand Müller-Rommel. Basingstoke: Palgrave. 179206.

Bowler, Shaun. 2010. "Private Members' Bills in the Uk Parliament: Is There an 'Electoral Connection'?" The Journal of Legislative Studies 16: 476-94.

Cox, Gary, and Matthew McCubbins. 2004. Setting the Agenda. Cambridge: Cambridge University Press.

"De-Politicize Railways, Create Independent Corporation." January 13, 2013. The Times of India.

Dowding, Keith, and Patrick Dumont. 2009. "Structural and Strategic Factos Affecting the Hiring and Firing of Ministers." In The Selection of Ministers in Europe, eds. Keith Dowding and Patrick Dumont. New York: Routledge.

French, Patrick. 2011. India: A Portrait. London: Penguin UK.

Jain, H.M. 2003. Indian Cabinet and Politics. New Delhi: Gyan.

Kellermann, Michael. 2016. "Electoral Vulnerability, Constituency Focus, and Parliamentary Questions in the House of Commons." The British Journal of Politics and International Relations 18: 90-106.

Kerby, Matthew. 2009. "Worth the Wait: Determinants of Ministerial Appointment in Canada, 19352008." Canadian Journal of Political Science 42: 593-611.

Klein, Elad, and Resul Umit. 2016. "The Electoral Connection of Ministerial Selection in the Uk." The Journal of Legislative Studies 22: 276-94.

Lok Sabha Secretariat. 2011. Council of Ministers, 1947-2011: Names and Portfolios of the Members of the Union Council of Ministers, from 15 August 1947 to 31 March 2011. Seventh edition New Delhi: Lok Sabha.

Martin, Shane. 2016. "Policy, Office and Votes: The Electoral Value of Ministerial Office." British Journal of Political Science 46: 281-96.

Mayhew, David R. 1974. Congress: The Electoral Connection. New Haven: Yale University Press.

Müller, Wolfgang C., and Kaare Strøm. 1999. Policy, Office, or Votes? How Political Parties in Western Europe Make Hard Decisions. Cambridge: Cambridge University Press.

Nicholson, Norman K. 1975. "Integrative Strategies of a National Elite: Career Patterns in the Indian Council of Ministers." Comparative Politics 7: 533-57. 
Nikolenyi, Csaba. 2004. "When the Central Player Fails: Constraints on Cabinet Formation in Contemporary India." Canadian Journal of Political Science 37: 395-418.

—. 2014. "India: The Selection and Deselection of Cabinet Ministers." In The Selection of Ministers around the World, eds. Keith Dowding and Patrick Dumont. Abingdon: Routledge.

- 2015. "Government Investiture in India: Formal Rules and Informal Practices." In Parliaments and Government Formation: Unpacking Investiture Rules, eds. Bjørn Erik Rasch, Shane Martin and José Antonio Cheibub.

O'Malley, Eoin. 2006. "Ministerial Selection in Ireland: Limited Choice in a Political Village." Irish Political Studies 21: 319-36.

Shrinivasan, Rukmini. August 4, 2015. "Only 8.15\% of Indians Are Graduates, Census Data Show." The Hindu.

Sisson, Richard. 1981. "Prime Ministerial Power and the Selection of Ministers in India: Three Decades of Change." International Political Science Review 2: 137-57.

Sridharan, E. 2012. "Why Are Multi-Party Minority Governments Viable in India? Theory and Comparison." Commonwealth 63 Comparative Politics 50: 314-43.

Strøm, Kaare. 1997. "Rules, Reasons and Routines: Legislative Roles in Parliamentary Democracies." The Journal of Legislative Studies 3: 155-74.

Wehner, Joachim. 2010. Legislatures and the Budget Process: The Myth of Fiscal Control. Basingstoke: Palgrave Macmillian.

Wilkenson, Steven I. 2014. "Patronage as Politics in Post-Independence India." In Patronage as Politics in South Asia, ed. Anastasia Piliavsky. Cambridge: Cambridge University Pres. 
Table 2. Ministerial Office and Electoral Outcomes

\begin{tabular}{|c|c|c|c|c|c|c|c|}
\hline & (1) & (2) & (3) & $(4)$ & (5) & (6) & $(7)$ \\
\hline \multirow[t]{2}{*}{ Ministerial Office } & $0.036^{* *}$ & $0.028^{*}$ & $0.025^{*}$ & $0.033^{* *}$ & $0.026^{*}$ & $0.027^{*}$ & $0.089^{* * *}$ \\
\hline & $(0.012)$ & $(0.011)$ & $(0.013)$ & $(0.012)$ & $(0.013)$ & $(0.013)$ & $(0.016)$ \\
\hline \multirow[t]{2}{*}{ Incumbent } & $0.314^{* * *}$ & $0.328^{* * *}$ & $0.163^{* * *}$ & $0.318^{* * *}$ & $0.159^{* * *}$ & $0.139^{* * *}$ & $0.137^{* * *}$ \\
\hline & $(0.004)$ & $(0.006)$ & $(0.006)$ & $(0.006)$ & $(0.006)$ & $(0.006)$ & $(0.006)$ \\
\hline \multirow[t]{2}{*}{ Governing Party } & & $0.149^{* * *}$ & $-0.011^{*}$ & $0.144^{* * *}$ & $-0.013^{* *}$ & $-0.022^{* * *}$ & $-0.023^{* *}$ \\
\hline & & $(0.004)$ & $(0.005)$ & $(0.004)$ & $(0.005)$ & $(0.005)$ & $(0.005)$ \\
\hline \multirow[t]{2}{*}{ Incumbent $*$ Government } & & $-0.148^{* * *}$ & $-0.051^{* * *}$ & $-0.147^{* * *}$ & $-0.051^{* * *} *$ & $-0.047^{* * * *}$ & $-0.046^{* * *}$ \\
\hline & & $(0.009)$ & $(0.009)$ & $(0.009)$ & $(0.009)$ & $(0.009)$ & $(0.009)$ \\
\hline \multirow[t]{2}{*}{ State Governing Party } & & & & & & $0.098^{* * *} *$ & $0.102^{* * *}$ \\
\hline & & & & & & $(0.004)$ & $(0.004)$ \\
\hline \multirow[t]{2}{*}{ Ministerial Office * State Gov Party } & & & & & & & $-0.124^{* * *}$ \\
\hline & & & & & & & $(0.022)$ \\
\hline Party fixed effects & No & No & Yes & No & Yes & Yes & Yes \\
\hline Constituency-year fixed effects & No & No & No & Yes & Yes & Yes & Yes \\
\hline \multirow[t]{2}{*}{ Constant } & $0.060^{* * *}$ & $0.047^{* * *}$ & $0.025^{* * *}$ & $0.048^{* * *}$ & $0.032^{* * *}$ & $0.031^{* * *}$ & $0.031^{\text {*** }}$ \\
\hline & $(0.001)$ & $(0.001)$ & $(0.003)$ & $(0.001)$ & $(0.004)$ & $(0.004)$ & $(0.004)$ \\
\hline R-squared & 0.270 & 0.342 & 0.655 & 0.388 & 0.676 & 0.696 & 0.698 \\
\hline $\mathrm{N}$ & 26,405 & 26,405 & 26,405 & 26,405 & 26,405 & 26,405 & 26,405 \\
\hline
\end{tabular}

Note: Robust standard errors clustered on individual candidates in parentheses

$* * *_{p}<0.001, *^{* *} p<0.01,{ }^{*} \mathrm{p}<0.05$ 


\section{Appendix}

The main analysis of executive particularism in Tables 2 and 3 employed OLS models. This appendix explores an alternative approach, using a series of difference-indifference models in consecutive elections. The small number of candidates who contested two successive elections means that the samples for those comparisons are far smaller than in the OLS models.

The "pre-treatment" period is the first election in the pair and the second is the treatment period. This is denoted by the dichotomous variable Time which takes a 0 in the first period and a 1 in the second. The treatment group is those MPs holding a ministerial office ahead of the election. The Ministerial Office variable takes a 1 for sitting government ministers and a 0 for all other candidates. The interaction between time and treatment is our difference-in-difference estimator. More advanced specifications include controls for membership in the ruling party and incumbency status as well as individual, party or constituency fixed effects.

In tables A1 and A2, the coefficients of the difference-in-difference estimator fails to achieve conventional levels of statistical significance in most instances. The only exception in each case is model 3 where the coefficient is negative, suggesting the treatment-holding ministerial office-reduces electoral success. In table A3 the difference-in-difference estimator is significant in every specification, however, the coefficient is consistently negative. In none of the tables does the difference-in-difference analysis indicate that holding ministerial office causes an increase in electoral performance. This is in line with the conclusions of the OLS model examined in table 3 of the article. 


\begin{tabular}{|c|c|c|c|c|c|}
\hline & (1) & $(2)$ & (3) & (4) & (5) \\
\hline Time & $\begin{array}{l}-0.020 \\
(0.011)\end{array}$ & $\begin{array}{l}-0.043^{* * *} \\
(0.009)\end{array}$ & $\begin{array}{l}-0.012 * * \\
(0.005)\end{array}$ & $\begin{array}{l}-0.022 * * * \\
(0.006)\end{array}$ & $\begin{array}{l}-0.038 * * * \\
(0.008)\end{array}$ \\
\hline Ministerial Office & $\begin{array}{l}0.206 * * * \\
(0.024)\end{array}$ & $\begin{array}{l}0.002 \\
(0.027)\end{array}$ & $\begin{array}{l}-0.003 \\
(0.020)\end{array}$ & $\begin{array}{l}0.053 \\
(0.034)\end{array}$ & $\begin{array}{l}0.050 \\
(0.040)\end{array}$ \\
\hline $\begin{array}{l}\text { Time*Ministerial Office } \\
\text { (DiD) }\end{array}$ & $\begin{array}{l}-0.034 \\
(0.029)\end{array}$ & $\begin{array}{l}-0.019 \\
(0.030)\end{array}$ & $\begin{array}{l}-0.043^{*} \\
(0.018)\end{array}$ & $\begin{array}{l}-0.045 \\
(0.036)\end{array}$ & $\begin{array}{l}-0.076 \\
(0.043)\end{array}$ \\
\hline Governing Party & & $\begin{array}{l}0.092 * * * \\
(0.009)\end{array}$ & $\begin{array}{l}0.025 \\
(0.020)\end{array}$ & $\begin{array}{l}-0.020 \\
(0.029)\end{array}$ & $\begin{array}{l}0.125 * * * \\
(0.013)\end{array}$ \\
\hline Incumbent & & $\begin{array}{l}0.224 * * * \\
(0.009)\end{array}$ & $\begin{array}{l}-0.029 * * * \\
(0.009)\end{array}$ & $\begin{array}{l}0.089 * * * \\
(0.009)\end{array}$ & $\begin{array}{l}0.154 * * * \\
(0.010)\end{array}$ \\
\hline Constant & $\begin{array}{l}0.275^{* * *} \\
(0.008)\end{array}$ & $\begin{array}{l}0.177^{* * *} \\
(0.008)\end{array}$ & $\begin{array}{l}0.283^{* * *} \\
(0.007)\end{array}$ & $\begin{array}{l}0.254^{* * *} \\
(0.010)\end{array}$ & $\begin{array}{l}0.191^{* * *} \\
(0.007)\end{array}$ \\
\hline Individual Fixed Effects & No & No & Yes & No & No \\
\hline Party Fixed Effects & No & No & No & Yes & No \\
\hline Constituency Fixed Effects & No & No & No & No & Yes \\
\hline $\mathrm{N}$ & 1660 & 1660 & 1660 & 1660 & 1660 \\
\hline$R-s q$ & 0.031 & 0.375 & 0.932 & 0.709 & 0.617 \\
\hline
\end{tabular}

Standard errors in parentheses. 1999 Election is the "pre-treatment" period

$* p<0.05 * * p<0.01 * * * p<0.001$ 


\begin{tabular}{|c|c|c|c|c|c|}
\hline & $(1)$ & $(2)$ & (3) & (4) & $(5)$ \\
\hline \multirow[t]{2}{*}{ Time } & $-0.048 * * *$ & $-0.073 * * *$ & $-0.033 * * *$ & $-0.058 * * *$ & $-0.065 * * *$ \\
\hline & $(0.011)$ & $(0.009)$ & $(0.004)$ & $(0.007)$ & $(0.011)$ \\
\hline \multirow[t]{2}{*}{ Ministerial Office } & $0.207 * * *$ & $-0.046^{*}$ & $0.067 * *$ & 0.018 & -0.021 \\
\hline & $(0.021)$ & $(0.022)$ & $(0.024)$ & $(0.023)$ & $(0.041)$ \\
\hline \multirow[t]{2}{*}{ Time*Ministerial Office (DiD) } & 0.016 & 0.035 & $-0.109 * * *$ & -0.002 & 0.005 \\
\hline & $(0.032)$ & $(0.032)$ & $(0.033)$ & $(0.034)$ & $(0.052)$ \\
\hline \multirow[t]{2}{*}{ Governing Party } & & $0.109 * * *$ & $0.015^{*}$ & $-0.027 *$ & $0.101 * * *$ \\
\hline & & $(0.011)$ & $(0.008)$ & $(0.011)$ & $(0.014)$ \\
\hline \multirow[t]{2}{*}{ Incumbent } & & $0.225^{* * *}$ & $-0.054 * * *$ & $0.097 * * *$ & $0.185^{* * *}$ \\
\hline & & $(0.009)$ & $(0.010)$ & $(0.011)$ & $(0.013)$ \\
\hline \multirow[t]{2}{*}{ Constant } & $0.237 * * *$ & $0.163 * * *$ & $0.250 * * *$ & $0.227 * * *$ & $0.173 * * *$ \\
\hline & $(0.008)$ & $(0.008)$ & $(0.004)$ & $(0.006)$ & $(0.009)$ \\
\hline Individual Fixed Effects & No & No & Yes & No & No \\
\hline Party Fixed Effects & No & No & No & Yes & No \\
\hline Constituency Fixed Effects & No & No & No & No & Yes \\
\hline $\mathrm{N}$ & 1500 & 1500 & 1500 & 1500 & 1500 \\
\hline R-sq & 0.053 & 0.375 & 0.931 & 0.700 & 0.611 \\
\hline
\end{tabular}

Standard errors in parentheses. 2004 Election is the "pre-treatment" period

$* p<0.05 * * p<0.01 * * * p<0.001$ 
Table A3: 2014 Election

\begin{tabular}{|c|c|c|c|c|c|}
\hline & $(1)$ & $(2)$ & (3) & (4) & (5) \\
\hline \multirow[t]{2}{*}{ Time } & $-0.029 * * *$ & $-0.052 * * *$ & $-0.017 * * *$ & $-0.042 * * *$ & $-0.047 * * *$ \\
\hline & $(0.009)$ & $(0.007)$ & $(0.004)$ & $(0.005)$ & $(0.007)$ \\
\hline \multirow[t]{2}{*}{ Ministerial Office } & $0.233^{* * *}$ & -0.001 & $0.065^{*}$ & $0.062 * *$ & -0.013 \\
\hline & $(0.022)$ & $(0.027)$ & $(0.028)$ & $(0.022)$ & $(0.034)$ \\
\hline \multirow[t]{2}{*}{ Time*Ministerial Office (DiD) } & $-0.079 * *$ & $-0.085^{* *}$ & $-0.150 * * *$ & $-0.101 * * *$ & $-0.108 * *$ \\
\hline & $(0.030)$ & $(0.033)$ & $(0.030)$ & $(0.030)$ & $(0.040)$ \\
\hline \multirow[t]{2}{*}{ Governing Party } & & $0.111^{* * *}$ & 0.011 & $-0.117 * * *$ & $0.113^{* * *}$ \\
\hline & & $(0.010)$ & $(0.017)$ & $(0.030)$ & $(0.012)$ \\
\hline \multirow[t]{2}{*}{ Incumbent } & & $0.211^{* * *}$ & $-0.052 * * *$ & $0.087 * * *$ & $0.175^{* * *}$ \\
\hline & & $(0.009)$ & $(0.010)$ & $(0.009)$ & $(0.011)$ \\
\hline \multirow[t]{2}{*}{ Constant } & $0.193 * * *$ & $0.137^{* * *}$ & $0.205^{* * *}$ & $0.210 * * *$ & $0.144 * * *$ \\
\hline & $(0.006)$ & $(0.006)$ & $(0.004)$ & $(0.007)$ & $(0.006)$ \\
\hline Individual Fixed Effects & No & No & Yes & No & No \\
\hline Party Fixed Effects & No & No & No & Yes & No \\
\hline Constituency Fixed Effects & No & No & No & No & Yes \\
\hline $\mathrm{N}$ & 2163 & 2163 & 2163 & 2163 & 2163 \\
\hline$R-s q$ & 0.036 & 0.322 & 0.911 & 0.676 & 0.538 \\
\hline
\end{tabular}

Standard errors in parentheses. 2009 Election is the "pre-treatment" period

$* p<0.05 * * p<0.01 * * * p<0.001$ 